\title{
Noni Juice (Morinda citrifolia) to Prevent Cancer Progression in Mice Induced DMBA and Cigarette Smoke Exposure
}

\author{
Didin Wahyu Agustina', Mulya Dwi Wahyuningsih" ${ }^{1}$, Sri Widyarti ${ }^{1}$, Aris Soewondo ${ }^{1}$, Hideo Tsuboi ${ }^{3}$, Muhaimin \\ Rifa'i $\mathbf{i}^{1,2, *}$
}

Didin Wahyu Agustina', Mulya

Dwi Wahyuningsih', Sri Widyarti', Aris Soewondo', Hideo Tsuboi ${ }^{3}$, Muhaimin Rifa' $\mathrm{i}^{1,2, *}$

'Biology Department, Faculty of Mathematics and Natural sciences, Brawijaya University. Malang 65145, East Java, INDONESIA.

${ }^{2}$ Biosystems Research Center, LPPM University of Brawijaya, Malang 65145, East Java, INDONESIA.

${ }^{3}$ Department of Immunology, Nagoya University Graduate School of Medicine, 65 Tsurumai-cho, Showa-ku, Nagoya 466-8550, JAPAN.

\section{Correspondence}

\section{Muhaimin Rifa'i}

Biology Department, Faculty of Mathematics and Natural sciences,

Brawijaya University; Biosystems Research

Center, LPPM University of Brawijaya,

Malang 65145, East Java, INDONESIA.

E-mail: rifa123@ub.ac.id

History

- Submission Date: 09-04-2020;

- Review completed: 02-05-2020;

- Accepted Date: 11-05-2020.

DOI : 10.5530/pj.2020.12.134

Article Available online

http://www.phcogi.com/v12/i5

\section{Copyright}

(C) 2020 Phcogj.Com. This is an openaccess article distributed under the terms of the Creative Commons Attribution 4.0 International license.

\begin{abstract}
Introduction: Accumulation of polycyclic aromatic hydrocarbons (PAH) in the body commonly lead to degenerative disease such as cancer. This study aims to investigate the potential of Morinda citrifolia to maintain the immune system against toxic exposure. Material and Methods: This study used Five weeks old male Balb/C mice as animal model. The 7,12-Dimethylbenz(a)anthracene (DMBA) was administrated for six weeks following with 3 days cigarette smoke (CS) exposure then treated with noni juice (M. citrifolia) for two weeks. Experimental animals were divided into six groups. Normal control (N); DMBA+CS; Cisplatin; D1; D2; and D3. Profil of CD4+TNF $\alpha^{+}, \mathrm{CD} 11 \mathrm{~b}^{+} \mathrm{IL} 6^{+}, \mathrm{CD} 11 \mathrm{~b}^{+} \mathrm{IFN} \gamma^{+}, \mathrm{CD} 4^{+} \mathrm{CD} 25^{+} \mathrm{IL} 10^{+}, \mathrm{NK}^{+} \mathrm{IL} 6^{+}$ cells was analyzed by flow cytometry and data was analyzed with one-way ANOVA and Post Hoc Tukey HSD test with a significance of $p$-values < 0.05 . Results: This study show that $\mathrm{DMBA}+\mathrm{CS}$ induction increasing level of $\mathrm{CD} 11 \mathrm{~b}+\mathrm{IL} 6^{+}, \mathrm{CD} 4^{+} \mathrm{CD} 25^{+} \mathrm{IL}-10^{+}$and $\mathrm{NK}+\mathrm{IL}-6^{+}$mean while decreasing CD4+TNF $\alpha{ }^{+}$significantly $(P<0.5)$ than Normal group. Noni juice in dose $90 \mathrm{mg} / \mathrm{Kg}$ BW decrease cytokine pro-inflammation (IL-6 and IFN $\gamma$ ) both in macrophage and NK cell profile significantly $(P<0.05)$. Noni juice in $30 \mathrm{mg} / \mathrm{Kg} \mathrm{BW}$ could improve the activation CD4 ${ }^{+} \mathrm{TNF} \alpha^{+}$ significantly $(P<0.05)$. Noni juice also has efficacy to control $T$ regulator activation to prevent tumor escape. Conclusion: These results suggest that noni juice has anti-cancer potencies by maintain homeostasis of immune system and could be immune herbal supplement.
\end{abstract}

Key words: Homeostatic, Immunotoxin, Inflammation, Tumor progression, Noni juice.

\section{INTRODUCTION}

Nowadays, it is almost impossible to avoid toxic exposure in our environment. A large number of people are injured or die each year as a result of exposure to both manufactured chemicals and natural toxins. ${ }^{1}$ Polycyclic aromatic hydrocarbons (PAH) are a major compound that easily found in the environment. ${ }^{2}$ Chronic exposure to 7,12-dimethylbenz[a]anthracene (DMBA) generated during the combustion of organic matter, including cigarette smoke, can cause degenerative illness to death. ${ }^{3} \mathrm{~A}$ mixture of chemical toxins can damage the DNA, which is leading to various diseases, including cancer., ${ }^{4,5}$ The human body can fight that toxic exposure through the immune system, but if we exposed for a long time, it could be harmful. That is why we needed to find a supplement that can work as an immune stimulation to maintain a homeostatic of the immune system.

Natural plant extracts have been used for thousand years by many cultures and civilizations as a basis for treating various types of diseases. More than $80 \%$ of the global population is currently dependent on natural plant extracts through traditional therapies. Researchers actively focus on research related to the development, treatment, and prevention of cancer with natural compounds. ${ }^{6}$ Morinda citrifolia is a fruit that easily found in a tropical country. ${ }^{7}$ Morinda citrifolia or known as noni fruits contain multiple beneficial nutrients for human beings because the abundant of flavonoid and other compounds as secondary metabolites. ${ }^{8,9}$ Flavonoid is an antioxidant that has been reportedly showed anticancer activity as a chemopreventive and angiogenesis agent. ${ }^{9-11}$

Morinda citrifolia has more than 160 identified chemical compounds; the main components are terpene compounds, anthraquinones, morindone, morindin, asperuloside, acubin, caproic acid, caprylic acid, damnacanthal, scopoletin, polysaccharide, and alkaloids. ${ }^{12}$ Experimental studies show that phytochemical substances with anti-oxidative and anti-inflammatory properties in noni fruits inhibit cancer formation and development. ${ }^{13}$

Despite a vital role of noni fruits for therapeutics properties, the research about the effect of noni juice in the stimulating immune system and prevent inflammation caused by toxin exposure is limited. Thus, this study aimed to investigate the effect of noni fruits in modulating the immune system by observing the profile of IL-10, IL- 6 , and NK cells in the $\mathrm{Balb} / \mathrm{c}$ mice DMDA-cigarette exposure.

\section{MATERIAL AND METHODS}

\section{Animal care}

Five weeks old male BALB/c mice were maintained in a pathogen-free chamber for acclimation. Experimental mice were divided into 
5 groups $(\mathrm{n}=5)$. All animal experiment in this study was approved by Brawijaya University Ethics Committee No 779-KEP-UB 2019.

\section{Experimental design}

Five-weeks-old male mice were treated with DMBA (Tokyo Chemical Industry Co. Ltd.) with corn oil as a solvent for twelve times administration in a six weeks. After that, the treatment group was exposure with cigarettes smoke for 3 days before orally treated with Noni fruits extract every day for 2 weeks. Mice were divided into five treatment groups: Normal control $(\mathrm{N}), \mathrm{DMBA}+$ Cigarette smoke injected mice (DMBA+CS), DMBA+ CS injected mice treated with Cisplatin $0.2 \mathrm{mg} / \mathrm{kg} \mathrm{BW}$ (Cisplatin), and DMBA+ CS injected mice treated with noni fruits $30 \mathrm{mg} / \mathrm{kg}$ BW (D1), DMBA+ CS injected mice treated with noni fruits $90 \mathrm{mg} / \mathrm{kg} \mathrm{BW}(\mathrm{D} 2), \mathrm{DMBA}+\mathrm{CS}$ injected mice treated with noni fruits $810 \mathrm{mg} / \mathrm{kg}$ BW (D3). All animals received the normal diet, and all of the mice were sacrificed on the eighth-weeks post-treatment.

\section{Cell isolation and antibody staining}

Mice were sacrificed by cervical dislocation and spleen was isolated and washed with phosphate-buffered saline (PBS) in Petri dishes. Splenic cells were isolated by crushing the organ in PBS. Homogenates were centrifuged, $2500 \mathrm{rpm}, 10^{\circ} \mathrm{C}$, for $5 \mathrm{~min}$. The supernatant was discarded while the pellet resuspended in $1 \mathrm{ml}$ of medium. As much as $2 \times 10^{6}$ cells were taken as and transferred into microtube $(1 \mathrm{~mL})$ then added $500 \mu \mathrm{L}$ PBS. The microtube was centrifuged at $2500 \mathrm{rpm}, 10^{\circ} \mathrm{C}$ for 5 minutes, according to Rifa'i et al. (2015) The pellet then stained with $100 \mu \mathrm{L}$ extracellular antibody at a final concentration of $0.005 \mathrm{mg} / 100$ $\mu \mathrm{L}$, then incubated at $4^{\circ} \mathrm{C}$ for $30 \mathrm{~min} . .^{14-15}$ The suspension was added by $200 \mu \mathrm{L}$ of a fixative solution (cytofix) and incubated in an icebox of $4^{\circ} \mathrm{C}$ for $20 \mathrm{~min}$. The fixative solution was washed with $500 \mu \mathrm{L}$ washperm solution by centrifugation at $2500 \mathrm{rpm}, 10^{\circ} \mathrm{C}$ for $5 \mathrm{~min}$. The supernatant was aspirated, the pellet was added by $100 \mu \mathrm{L}$ intracellular antibody at a final concentration of $0.005 \mathrm{mg} / 100 \mu \mathrm{L}$ and then incubated at $4{ }^{\circ} \mathrm{C}$ for $20 \mathrm{~min}$. The cells were then resuspended and added with $400 \mu \mathrm{L}$ PBS then transferred to a cuvette and analyzed using flow cytometry with BDCellquest ProTM software. The combination of antibodies and fluorochromes that used in this study were the FITC-conjugated rat anti-mouse CD11b, PE-conjugated rat anti-mouse IFN- $\gamma$, PE/Cy5- conjugated rat anti-mouse IL-6; FITC-conjugated rat anti-mouse CD4, PE-conjugated rat anti-mousecTNF $\alpha$, FITC-conjugated rat anti-mouse $\mathrm{CD} 4, \mathrm{PE}$-conjugated rat anti-mouse $\mathrm{CD} 25, \mathrm{PE} / \mathrm{Cy} 5$-conjugated rat antimouse IL-10; and FITC-conjugated rat anti-mouse NK, PE-conjugated rat anti-mouse IL-6 (BioLegend, San Diego).

\section{Data analysis}

The relative number of the cells obtained from flow cytometry was analyzed using BDCellquest ProTM software. Then, the data were analyzed using One Way ANOVA with $\mathrm{p}<0.05$ and followed with Host Tukey HSD significance of 0.05 test to know the real difference between treatment groups.

\section{RESULT}

Noni fruits extract regulate pro-inflammatory cell for cancer prevention

Inflammation is an immune response that can be triggered by a variety of factors, including pathogens, damaged cells, and toxic compounds. In this study we observe the inflammation process by evaluate increasing a relative number of $\mathrm{CD} 4^{+} \mathrm{TNF} \alpha^{+}$; $\mathrm{CD} 11 \mathrm{~b}^{+} \mathrm{IFN} \gamma^{+}$ and $\mathrm{CD} 11 \mathrm{~b}^{+} \mathrm{IL}-6^{+}$. As shown in Figure 1, DMBA+CS exposure decrease significantly $(\mathrm{P}<0.05)$ the relative number of $\mathrm{CD}^{+}{ }^{+} \mathrm{TNF}^{+}$to $3.68 \pm 0.92 \%$ from $8.99 \pm 1.3 \%$ (Normal Group). Treatment with noni juice could improve the activation of $\mathrm{CD} 4{ }^{+} \mathrm{TNF}^{+}$into $8.48 \pm 1.5 \% ; 12.25 \pm 1.6 \%$ and $10.38 \pm 2.3 \%$.

Oppositely, the percentage of CD11 $\mathrm{b}^{+} \mathrm{IFN} \gamma^{+}$and CD11b+IL- $6^{+}$in DMBA-CS group was significantly $(\mathrm{P}<0.05)$ higher than normal group (21.01\% and $41.2 \%)$. Thus, in our observation, we found that Noni juice 90 and $810 \mathrm{mg} / \mathrm{kg} \mathrm{BW}$ could reduce activation of CD11 $\mathrm{b}^{+} \mathrm{IFN} \gamma^{+}$ (13.43\%; 12.23\%) and CD11b+IL-6 (20.68\%; 20.26\%) similar to normal group (Figure 2).

\section{Noni fruits extract stabilized T reg activation}

Immune system response to inflammation by secreting a cytokine of anti-inflammation. Excessive of IL-10 activation in Treg cell can prohibit pro-inflammatory cells in response to a carcinogenic agent such as DMBA that was leading to cancer formation. As a result of

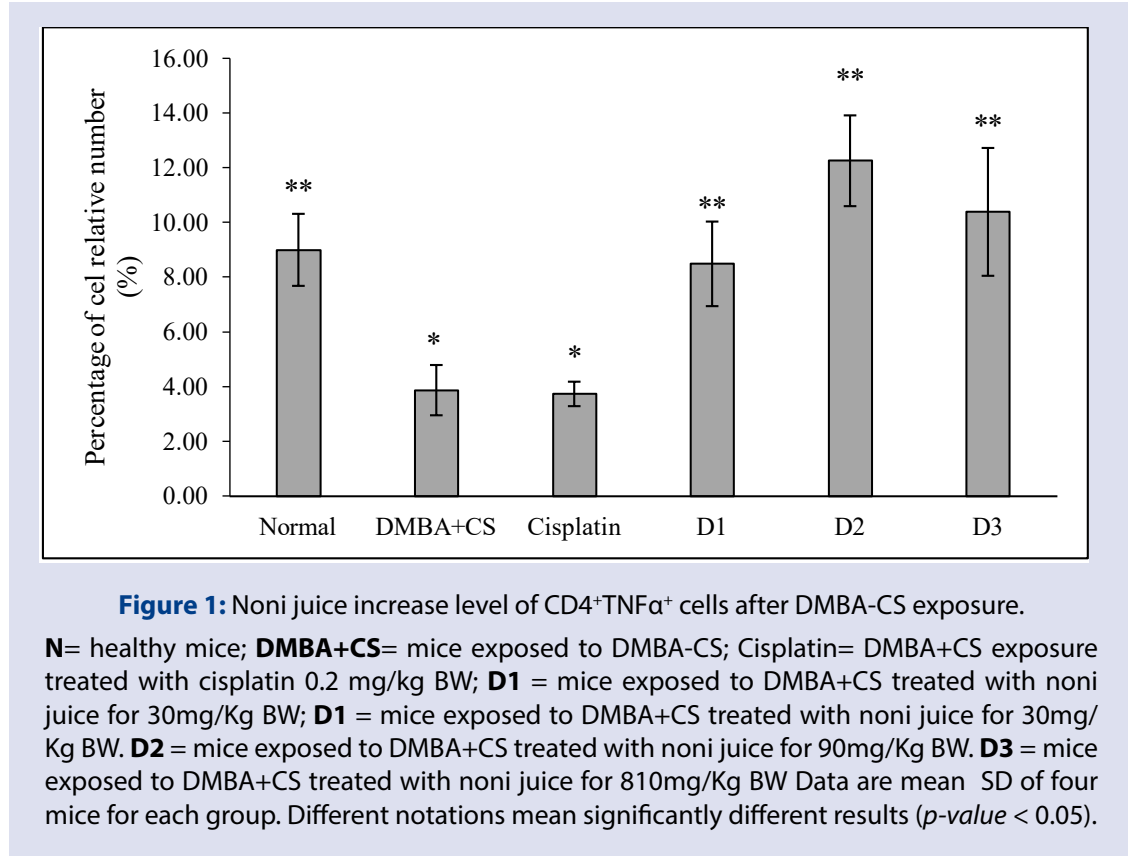


Activation pro-inflammatory cell in $\mathrm{DMBA}+\mathrm{CS}$ group, percentage relative cell number of $\mathrm{CD} 4^{+} \mathrm{CD} 25^{+} \mathrm{IL}-10^{+}$also increase into $17.2 \%$. Those percentage are higher comparing with normal group with $11.92 \%$ $(\mathrm{P}<0.05)$. All treatment group both cisplatin and Noni juice could lowering the percentage of cell relative number of $\mathrm{CD} 4^{+} \mathrm{CD} 25^{+} \mathrm{IL}-10^{+}$ similar into normal.

\section{Noni fruits extract suppressed natural killer (NK) cells activation}

DMBA is a chemical compound with the ability to cause the growth of cancer cells and enhance tumor progression. Natural killer (NK) cells directly recognize the tumor cells in the body. Profile of NK cells in the normal group showed only $24 \%$ NK cells was activated. The highest level of NK was shown in Cancer Group (43\%), indicating that NK cell was being activated as a respond of an innate immune system against lung cancer. This result shows that administration of Noni extract to DMBA-cigarette smoke exposure mice model decrease NK cells in the spleen although, Treatment group D1 and D2 could decrease NK $\mathrm{IL}^{-} 6^{+}$ significantly come to Normal group (Figure 4).

\section{DISCUSSION}

Toxic exposure from chronic polycyclic aromatic hydrocarbons family and has been known as immunotoxin. ${ }^{2}$ Thus, in this present study, we observed DMBA-cigarette smoke exposure in mice models followed by increasing inflammation incidence. The correlation between inflammation and degenerative disease, especially cancer, has shown by high expression of pro-inflammatory cytokines in immune cells surrounding tumor microenvironment. ${ }^{16}$ Based on this experiment, it has confirmed inflammation incidence, which was evaluated by the appearance of macrophages relative number, which significantly producing pro-inflammatory cytokines $\mathrm{CD} 11 \mathrm{~b}^{+} \mathrm{IFN} \gamma^{+}$, CD11b+IL-6 $6^{+}$, also higher level in NK+IL-6 $6^{+}$in DMBA-cigarette smoke exposure mice model. Similar to those results above, a study conducted by Xiao et al. (2013) has shown significant promoted numbers of macrophages followed with high inflammation incidence. ${ }^{17}$ However, oppositely, those relative numbers were significantly decreased after noni juice treatment (Figures 2 and 4 ).
Moreover, many experimental studies have been identified that increasing inflammation followed by the recruitment of immunecompetent cells fencing in the tumor microenvironment. ${ }^{16,18}$ In this study, we found that IL- 6 and IFN $\gamma$ expression in macrophage was significantly increased in the DMBA-cigarette smoke exposure mice model (Figure 2). Macrophages can secrete IL-6 in response to specific microbial molecules or toxic agents. ${ }^{19}$ In Cancer promotion, IL-6 has been shown to activate signaling pathways that lead to tumor proliferation. ${ }^{20}$ IL-6-induced JAK/STAT activation leads to constitutive activation of STAT3, which has been correlated with enhanced tumor cell growth and resistance to chemotherapy. ${ }^{21}$ Releasing of IL- 6 also induces intracellular signaling cascades that give rise to inflammatory cytokine production.

Inflammation that occurs during DMBA-cigarette smoke exposure suggests activation of $\mathrm{T}$ regulatory cells by production cytokine antiproliferation like IL-10 or TGF- $\beta$. Those cytokines act as an inhibitor of Th1, macrophage, NK, and cytotoxic cell activation. It was shown in the level of IL-10 secreted by T regulatory cells was higher in the DMBA-cigarette smoke exposure group than the normal group (Figure 3). Immune response by $T$ regulator activating was an excellent way to suppress inflammation and prevent tumor progression. However, the abundance of infiltrating Treg in the immunosuppressive tumor microenvironment (TME) resulting in tumor escape by suppressing the activation of an antitumor immune response. As shown in Figure 1, $\mathrm{DMBA}+\mathrm{CS}$ exposure suppress activation of of $\mathrm{CD} 4^{+} \mathrm{TNFa}^{+}$as immune response against immunotoxin. DMBA or other $\mathrm{PAH}$, and also cigarette smoke can act as immunosuppression, either humoral or cellular immunity including the decrease of recovery ability in lymphoid cells, apoptosis of pre-B cells, decreased of B cell capacity in producing antibodies, suppression of $\mathrm{T}$ cell and $\mathrm{B}$ cell proliferation and activation. ${ }^{22}$ In various types of cancer, the presence of high Treg cells and a low ratio of $\mathrm{CD}^{+} \mathrm{T}$ cells to Treg cells in the TME are related to cancer prognosis. ${ }^{23}$ Control of activation Treg cell and Pro-inflammation cell in the immune system are essential to the established immune system against tumor progression. ${ }^{15,24}$ This study reveal that administration of noni juice could increasing activation level of $\mathrm{CD} 4^{+} \mathrm{TNF}^{+}$as antitumor cells, whereas decreasing activation of $\mathrm{CD} 4^{+} \mathrm{CD} 25^{+} \mathrm{IL}-10^{+}$as antiinflammatory cells.

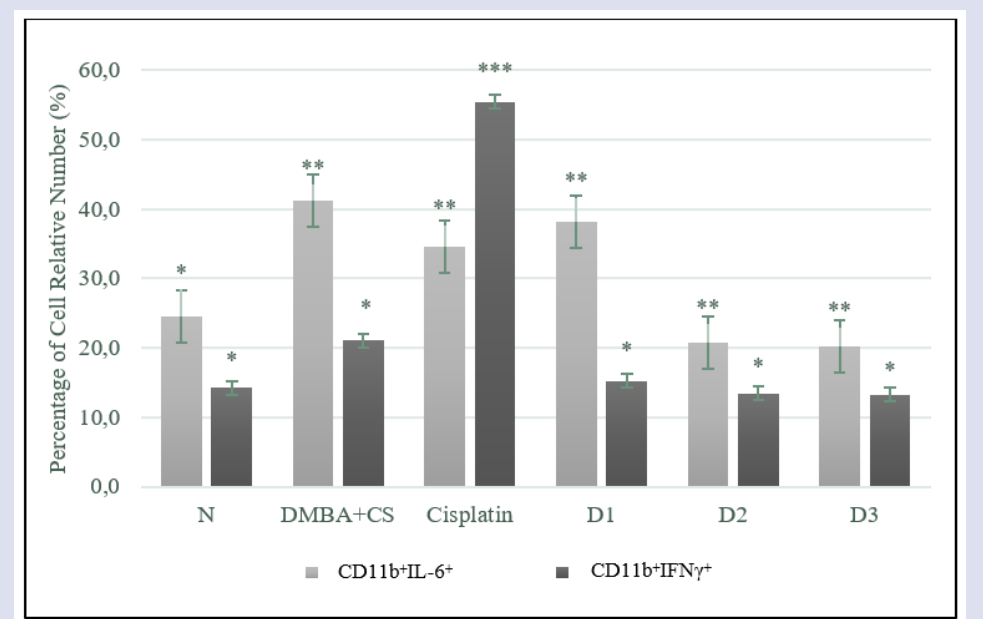

Figure 2: IFN- $\gamma$ and IL-6 expression on CD11b cells after DMBA-CS exposure and Noni juice treatment.

$\mathbf{N}=$ healthy mice; $\mathbf{D M B A}+\mathbf{C S}=$ mice exposed to DMBA-CS; Cisplatin= DMBA+CS exposure treated with cisplatin $0.2 \mathrm{mg} / \mathrm{kg}$ BW; $\mathbf{D} 1$ = mice exposed to DMBA+CS treated with noni juice for $30 \mathrm{mg} / \mathrm{Kg} \mathrm{BW}$; D1 = mice exposed to DMBA+CS treated with noni juice for $30 \mathrm{mg} / \mathrm{Kg}$ BW. D2 = mice exposed to DMBA+CS treated with noni juice for $90 \mathrm{mg} / \mathrm{Kg}$ BW. D3 = mice exposed to DMBA+CS treated with noni juice for $810 \mathrm{mg} / \mathrm{kg}$ BW Data are mean SD of four mice for each group. Different notations mean significantly different results $(p$-value $<0.05)$. 


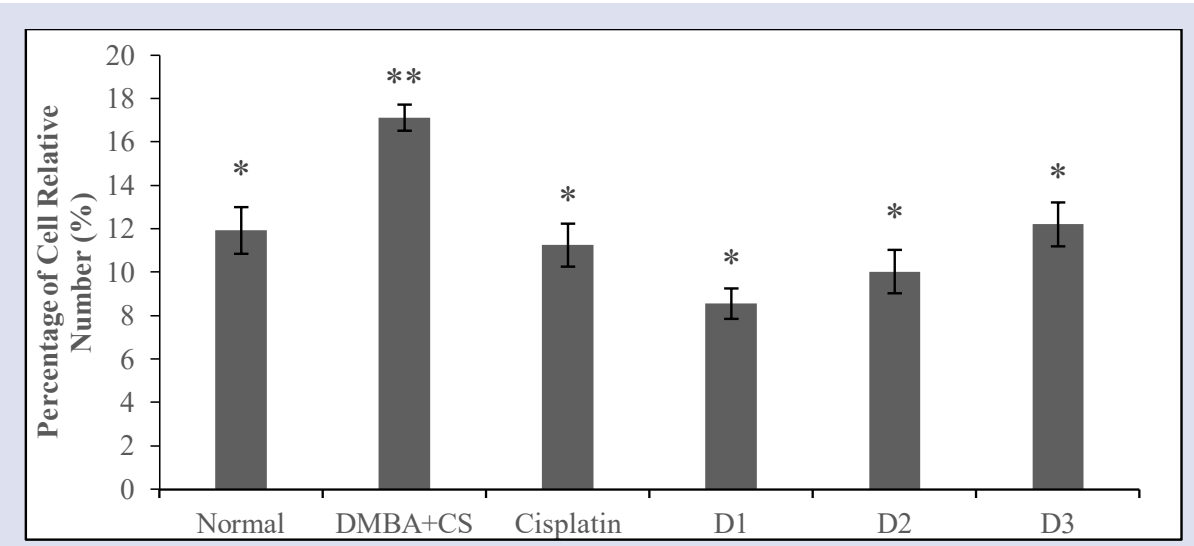

Figure 3: Expression of $\mathrm{CD} 4{ }^{+} \mathrm{CD} 25^{+} \mathrm{IL}-10^{+}$cells after DMBA-CS exposure and Noni juice Treatment. $\mathbf{N}=$ healthy mice; $\mathbf{D M B A}+\mathbf{C S}=$ mice exposed to DMBA-CS; Cisplatin= DMBA+CS exposure treated with cisplatin $0.2 \mathrm{mg} / \mathrm{Kg} \mathrm{BW}$; D1 = mice exposed to DMBA+CS treated with noni juice for $30 \mathrm{mg} / \mathrm{Kg} \mathrm{BW}$; D1 = mice exposed to DMBA+CS treated with noni juice for $30 \mathrm{mg} / \mathrm{Kg}$ BW. D2 = mice exposed to $\mathrm{DMBA}+\mathrm{CS}$ treated with noni juice for $90 \mathrm{mg} / \mathrm{Kg}$ BW. D3 = mice exposed to DMBA+CS treated with noni juice for $810 \mathrm{mg} / \mathrm{kg}$ BW Data are mean SD of four mice for each group. Different notations mean significantly different results ( $p$-value $<0.05)$.

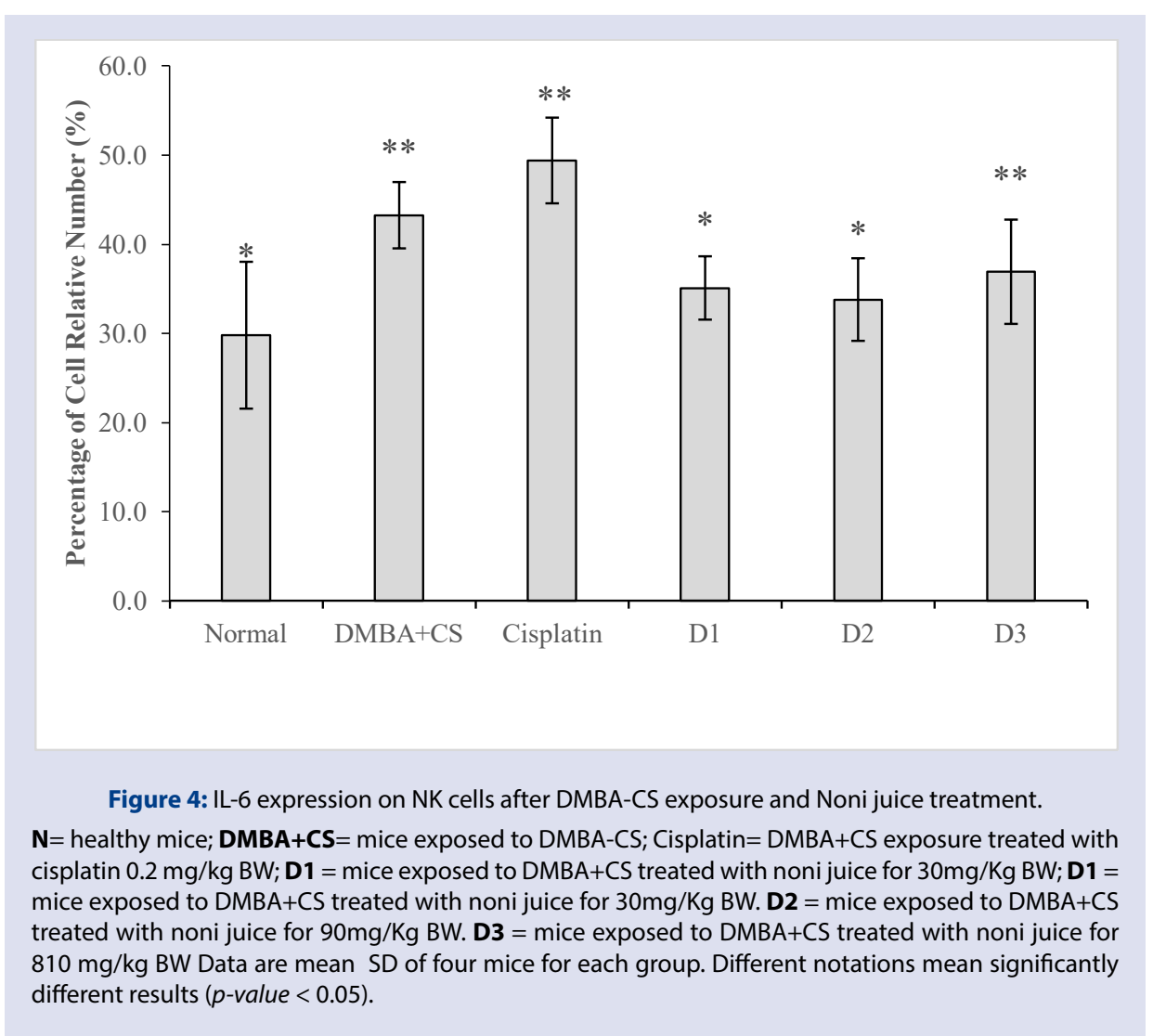

This study reveals that noni fruits can maintain both of cytokine of pro-inflammation and anti-inflammation to provide homeostatic cell. It showed in the group that given by noni juice have a similar profile in $\mathrm{CD}^{+} \mathrm{TNF}^{+}, \mathrm{CD} 11 \mathrm{~b}^{+} \mathrm{IL}^{+}, \mathrm{NK}^{+} \mathrm{IL} 6^{+}$, and $\mathrm{CD} 4^{+} \mathrm{CD} 25^{+} \mathrm{IL}-10^{+}$ with the normal group. Between 3 dosage that used in this study D2 $(90 \mathrm{mg} / \mathrm{kg} \mathrm{BW})$ and $\mathrm{D} 3(810 \mathrm{mg} / \mathrm{kg} \mathrm{BW})$ suggest better result than D1 $(30 \mathrm{mg} / \mathrm{Kg} \mathrm{BW})$ and cisplatin. More recent evidence revealed that noni fruits contain polyphenols and flavonoids, which help to reduce the risk of degenerative diseases, such as cancer and cardiovascular diseases. ${ }^{25,26}$ Several in-vitro and in-vivo studies have shown that Noni fruits have antioxidant, anti-inflammatory, anti-dementia, liverprotective, anticancer, analgesic, and immunomodulatory effects. Noni fruits have selective inhibition cyclooxygenase enzymes (COX) and even anti-inflammatory activity. ${ }^{27}$ Morindone, damnacanthal, and morindin are vital anthraquinone prevent tumor progression by inhibiting RAS activation..$^{28,29}$ So far, those studies above were correlated with our finding, the bioactive compounds from noni fruits probably prevent cancer formation caused by DMBA-cigarette smoke exposure by controlling inflammation and $\mathrm{T}$ regulator activation in mice model. 


\section{CONCLUSION}

Noni Juice with certain dose potentially maintain the immune system homeostasis from DMBA and cigarette smoke exposure. Noni juice with $90 \mathrm{mg} / \mathrm{kg}$ BW decrease inflammation in Macrophage and NK cell to prevent chronic inflammation. Meanwhile improve activation of $\mathrm{CD} 4{ }^{+} \mathrm{TNFa}^{+}$to fight against immunotoxin exposure. Noni juice also maintain activation of Treg cell in normal percentage to prevent tumor escape. Thus, the overall result of this research suggesting the potential of Noni juice as herbal drug to prevent tumor progression and recover immune system against immunotoxin.

\section{CONFLICTS OF INTEREST}

All Author declare that there is no conflicts interest in this study.

\section{REFERENCES}

1. Paul BT, Clement GY, Anita K.P, Dwayne JS. Heavy Metals Toxicity and Enviroment, EXS 2012;101:133-64.

2. Latif $W$, Anjum $A$, Jawed AU. Lead toxicity: a review. Interdiscip toxicol. 2015;8(2):55-64

3. Gao J, Lauer FT, Mitchell LA, Burchiel SW. Microsomal epoxide hydrolase is required for 7,12-dimethylbenz[a]anthracene (DMBA)-induced immunotoxicity in mice. Toxicological Science. 2007;98(1):137-44

4. Irfan AR, Wee YK, Woon KP, Jeonghui L. The Sources of Chemical Contaminants in Food and Their Health Implications. Front Pharmacol 2017;2017:1-7.

5. Nerin C, Alfaro P, Aznar M, and Dome-o, C. The challenge of identifying nonintentionally added substances from food packaging materials: a review. Anal Chim Acta. 2013;775:14-24

6. Alamode TT. An overview of the anti-cancer properties of some plants used in traditional medicine in Nigeria. Journal of Biochemistry and Bioinformatics. 2013;3(1):7-14.

7. Elujoba A.A., Odeleye O.M., Ogunyemi C.M. Traditional medicine development for medical and dental primary health care delivery system in Africa. African Journal of Traditional, Complementary and Alternative Medicines. 2005;2(1):4661.

8. Ui-Jong Y, Eun-Jung P, Tamara PK, Mayuramas SN, Marissa MW, Yanshang W et al. Anti-inflammatory and Quinone Reductase Inducing Compounds from Fermented Noni (Morinda citrifolia) Juice Exudates. Journal of Natural Product, 2015;79(6):1508-13

9. Hong YH, Yi Y, Han SY, Aziz N, Kim HG, Park SH, et al. Morinda citrifolia non water extract enhances innate and adaptive immune responses in healthy mice, ex vivo, and in vitro. Phytotherapy Research. 2019;33(3):676-89.

10. Stefany GS, Lorena AO, Diva AM, Tarcisio VB, Jalles AB, Cynthia MCP, et al Chemical structure and anti-inflammatory effect of polysaccharide extracted from Morinda. citrifolia Linn (Noni). Carbohidrat Polymer. 2015;197:515-23.

11. Senthilkumar S, Deepa K, Suganya M, Janakarajan J, Muralidharan J, Vasanthakumar P. Therapeutic Properties of Noni (Morinda citrifolia) and Its Products. International Journal Science Environment. 2016;5(3):1496-502.
12. Wang MY, Su C. Cancer preventive effect of Morinda citrifolia (Noni). Annals of the New York Academy of Sciences. 2001;952:161-8.

13. Sharma K, Pachauri SD, Khandelwal K, Ahmad H, Arya A, Biala P, et al. Anticancer Effects of Extracts from the Fruit of Morinda Citrifolia (Noni) in Breast Cancer Cell Lines. Drug Res. 2016;66(3):141-7.

14. Dwijayanti DR, Djati MS, Rifa'i, M. Decreasing the expression level of macrophage cell, pro-inflammatory cytokines and NF-kB using VipAlbumin in vitro. Asian Journal of Cell Biology. 2015;10:43-56.

15. Rifa'i, M., \&Widodo, N. Significance of propolis administration for homeostasis of CD4+CD25+T immunoregulatory cells controlling hyperglycemia. Springer Plus, 2014;(3):526.

16. Allavena P, Sica A, Solinas G, Porta C, Mantovani A. The inflammatory microenvironment in tumor progression: The role of tumor-associated macrophages. Crit Rev Oncol Hematol. 2008;66(2008):1-9.

17. Xiao Z, Jiang Q, Willette-Brown J, Xi S, Zhu F, Burkett $S$, et al. The pivotal role of IKK $\alpha$ in the development of spontaneous lung squamous cell carcinomas. Cancer Cell. 2013;23(4):527-40.

18. Elizabeth AC, Robert LB, Maria K. Underlying Causes and Therapeutic Targeting of the Inflammatory Tumor Microenvironment. Front Cell Dev Biol. 2018;6:56.

19. Guillermo AD, Albert D. Macrophage Cytokines: Involvement in Immunity and Infectious Diseases. Front Immunol. 2014;5:491.

20. Browning L, Patel MR, Horvath EB, Tawara K, Jorcyk CL. IL-6 and ovarian cancer: inflammatory cytokines in promotion of metastasis. Cancer Manag Res. 2018;10:6685-93.

21. Daniel EJ, Rachel AO, Jennifer RG. Targeting the IL-6/JAK/STAT3 signalling axis in cancer. Nat Rev Clin Oncol. 2018;15(4):234-48.

22. Burchiel SW, Luster MI. Signaling by environmental polycyclic aromatic hydrocarbons in human lymphocytes. Clinical Immunology. 2001;98(1):2-10.

23. Yoshihiro O, Hiroyoshi N. Regulatory T (Treg) cells in cancer: Can Treg cells be a new therapeutic target? Cancer Science. 2019;110(7):2080-9.

24. Christina M, Paluskievicz, Xuefang C, Reza A, Pan Z, Yang L, Jonathan SB. T Regulatory Cells and Priming the Suppressive Tumor Microenvironment. Front Immunol. 2019;10:2453.

25. Edipo SA, Debora O, Dachamir. Properties and Applications of Morinda citrifolia (Noni): A Review. Comprehensive Review in Food Science and Food Safety. 2019;18:883-909.

26. Wang M, Su C. Cancer preventive effect of Morinda citrifolia (Noni). Ann N Y Acd Sci. 2001;952:161-8.

27. Dalsgaard PW, Potterat O, Dieterle F, Paululat T, K"uhn T, Hamburger $M$ Noniosides $\mathrm{E}-\mathrm{H}$, new trisaccharide fatty acid estersfrom the fruit of Morinda citrifolia (noni). Planta Medica. 2006;72(14):1322-7.

28. Dussossoy E, Bony E, Michel A, Boudard F, Giaimis J, Brat P, Vaillant F. Antioxidative and anti-inflammatory effects of the Morinda citrifolia fruit (Noni). Acta Horticulturae. 2014;1040:69-74.

29. Torres MAO, deF'atima BM, Mond`ego-Oliveira R, deS'a JC, Rocha AL, AbreuSilva AL. One plant, many uses:A review of the pharmacological applications of Morinda citrifolia. Phytotherapy Research. 2017;31(7): 971-9. 


\section{GRAPHICAL ABSTRACT}

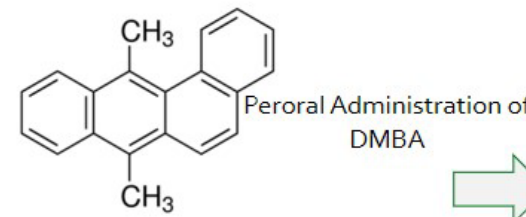

Cigarette Smoke Expossure

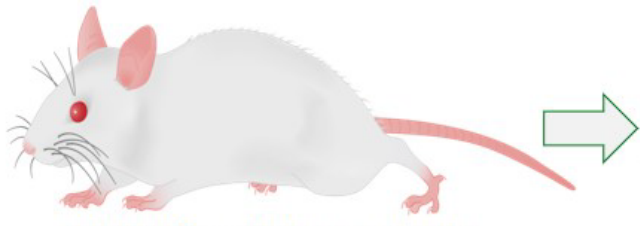

BALB/c Mice with Immunotoxicity
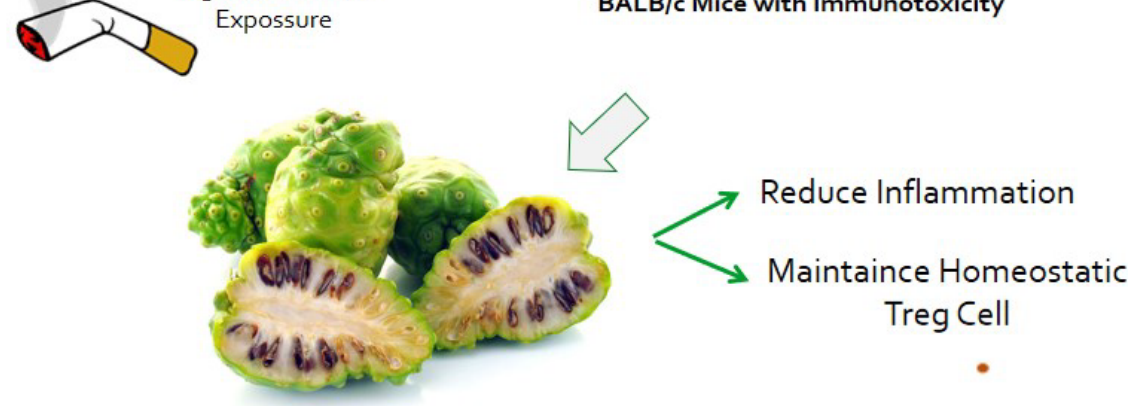

Treg Cell

\section{Noni Juice Treatment}

\section{ABOUT AUTHORS}

- Didin Wahyu Agustina, M.Si: Master Graduate Student in Biology Department, Faculty of Science, Brawijaya University, Indonesia. Main Research interest are drug discovery and immunology cancer.

- Mulya Dwi Wahyuningsih, M.Si: Master Graduate Student in Biology Department of Brawijaya University. Main Research interest are Biomolecular and immunology.

- Drs. Aris Soewondo, M.Si: Lecture in Biology Department, Faculty of Science, Brawijaya University, Indonesia. Main Research Interest are Animal Anatomy, Physiology and Histopathology.

- Dr. Sri Widyarti, M.Si: Lecture in Biology Department, Faculty of Science, Brawijaya University, Indonesia. Main Research Interest are Biology cell mechanism, Biomolecular and Nano Technology.

- Dr. Hideo Tsuboi: Associate Professor in Department of Immunology, Nagoya University Graduate School of Medicine, Japan. Main Research interest are Immunology and Biomedicine.

- Prof. Muhaimin Rifa'I, S.Si., Ph.D.Med.Sc.: Professor Biology Department, Faculty of Science, Brawijaya University, Indonesia. Main Research Interest are in Immunology, Pharmacology and Drug Discovery.

Cite this article: Agustina DW, Wahyuningsih MD, Widyarti S, Soewondo A, Tsuboi H, Rifa M. Noni Juice (Morinda citrifolia) to Prevent Cancer Progression in Mice Induced DMBA and Cigarette Smoke Exposure. Pharmacogn J. 2020;12(5):946-51. 